\title{
Legitimisation Strategies and Managerial Capture: A Critical Discourse Analysis of Employment Relations in Nigeria
}

Irrespective of the fundamental role of legitimacy in industrial relations as well as social and organisational life, little is known of the subtle meaning-making strategies through which organisational concepts, such as employment relations and engagement, are legitimised in modern world of work, particularly in developing countries such as Nigeria, which results in managerial capture. As a result, this paper explores the discursive legitimisation strategies used when making sense of employment relations in Nigeria's conflictual, non-participatory employment relations terrain. Relying on Leeuwen's (1995) legitimisation strategies, critical discourse analysis (CDA) and call by Bailey, Luck \& Townsend (2009) and Legge (1995) to widen employment relations discourse, we explore interview, focus group and shadow report data, and distinguish and analyse five legitimisation strategies. The strategies include authorisation, moralisation, mythopoesis, rationalisation, and management. Therefore, we contend that while these specific legitimisation strategies appear in separate data source, their recurrent manifestation and application underscores legitimising discourse of managerial capture in Nigeria's employment relations.

Keywords: Employment relations, CDA, legitimacy theory, legitimisation, managerialism, managerial capture/control, employers, employees, Nigeria

\section{Introduction}

Legitimacy is an important concept in understanding organisational practice and behaviour (Suchman, 1995; Suddaby \& Greenwood, 2005; Vaara, Tienari \& Laurila, 2006), human resource management (HRM) (Greenwood, 2012; Greenwood, Oliver, Sahlin \& Suddaby, 2008) and, in particular, employment relations (henceforth, ER) (Koca-Helvaci, 2015; Bailey, Luck \& Townsend, 2009; Francis, 2007). Although organisational analysis has conventionally emphasised the normative and cognitive rationale for legitimacy (Vaara \& Tienari, 2008), recent studies have taken the discursive approach to understanding organisational practice and legitimacy (Siltaoja \& Onkila, 2013; Luyckk \& Janssens, 2016). For example, Koca-Helvaci (2015) drawing upon appraisal theory and Leeuwen's (1995) legitimation theory, explores how the interplay between evaluative language and legitimation strategies contributes to Walmart's representation of its stance towards its associates and suppliers as the company faced claims of violations of labour rights in its own branches and supplier factories.

In the context of HRM - specifically ER - institutionally oriented writers (Kaufman, 2011; Greenwood et al., 2008) have explored legitimacy (legitimisation) from the prism of (new) institutionalism. Kaufman (2011) refers to institutional oriented issues central to legitimising organisational behaviour as "institutions matter", which influence actions, norms, and beliefs thus shaping outcomes. Some scholars (Beaumont, Hunter \& Sinclair, 1996; Ackroyd, Burrell, Hughes \& Whitaker, 1988) have investigated legitimacy from the perspective of social constructionism. For example, in an important study by Ackroyd, Burrell, Hughes \& Whitaker (1988), they observed that companies find it easier to implement change such as variation in ER processes, "if they can point to some "external" force which requires to be satisfied: e.g. the competitive gains of rival firms who have adopted'" (Beaumont, Hunter \& Sinclair, 1996, p. 18) comparable methods or pressures from customers for new standards. These writers have emphasised how specific and contextual corporate action can become politicised as well as how the legitimacy of these actions and organisation as a whole may be questioned as a consequence. Irrespective of these developments in understanding ER and 
legitimisation (and political) processes, researches that would highlight the concrete discursive strategies applied to legitimise or delegitimise organisational actions are lacking (Koca-Helvaci, 2015). Specifically, there is dearth of perspectives (Vaara, et al, 2006), which would allow one to examine the strategic and political aspects of discursive legitimisation.

Thus, first in this paper, we wish to complement extant literature on institutional oriented researches on ER and legitimacy by specifically focusing on the discursive - linguistic strategies used to legitimise organisational action in Nigeria's conflictual, non-participatory ER terrain (Otobo, 2016; Ubeku, 1983). We chose Nigeria, which is currently under-studied (Budhwar \& Debrah, 2004). It also has a history of problematic ER (Otobo, 2016) and one of the important players in developing countries ER discourse (Wood, 2008). In particular, our paper focuses on the petroleum, banking and the ICT sectors that constitute more than $90 \%$ of the country's GDP (Idemudia, 2010; Achua, 2008). For this purpose, we use CDA to analyse data. CDA deals with how texts represent organisational and social practices (Fairclough, 1992) with particular emphasis on understanding power relations (Wodak \& Meyer, 2009) in ER (Koca-Helvaci, 2015) and "representation gap" (Acas, 2012, p. 2). Second, by using CDA, we respond to the call by Bailey, Luck \& Townsend (2009, p. 285) to broaden perspectives on "new industrial relations" discourse for alternative views and voice to be heard (Legge, 1995). CDA can be instrumental in bringing alternative views to the fore (Fairclough, 2014), in particular, ER. This is because "employees want some form of 'voice' at work which will help them deal with problems ... In particular, they want "more cooperative styles of engagement with management which help improve their firm performance and their working lives" (Acas, 2012, p. 2-3).

Our approach is consistent with prior studies (Bailey, Luck \& Townsend, 2009; KocaHelvaci, 2015) that have used critical approach to ER and LT (Vaara \& Tienari, 2008). CDA also facilitates understanding organisational discourses and how they change to respond to organisational realities. According to Fairclough (1992, p. 8) "changing discourse practices contributes to change in knowledge ... social relations and social identities". Thus, in order to change perception about ER, discursive strategies that legitimise and naturalise management practice are traditionally applied (Koca-Helvaci, 2015). Third, by leveraging on unconventional data source - shadow reports - we also add to the body of methodologies adopted in mainstream literature on ER, HRM and general management, which include observation, ethnography, questionnaires and others. It is hoped that this study will add to existing literature on ER and LT in developing countries (Otobo, 2016) such as Nigeria. The main research question that this chapter hopes to answer is:

- What discursive legitimisation strategies are used to managerially capture ER in Nigeria?

In answering the above question, attention will be focused on five main discursive legitimisation strategies that aid to legitimise managerial capture in Nigeria's ER. These are Leeuwen's (1995) four discursive legitimisation strategies, which include authorisation, moralisation, mythopoesis, and rationalisation. We further extend these by adding management, which the companies use to legitimise ER. (See Table 1 for more detail). The emphasis here is to use CDA to unpack lexical pattern and strategies in data, which help to legitimise (Fairclough, 2014) and naturalise ER (Wodak \& Meyer, 2009). The paper is structured as follows. First, we present LT; second, managerial capture and legitimisation of ER is explained; third, Nigeria's socio-cultural, economic and employment context of employment relation is given. Fourth, we showed how we developed the paper's conceptual 
framework; fifth, methodology is explained; sixth findings and discussion is discussed; finally, summary and conclusions is presented.

\section{Legitimacy Theory (LT)}

Numerous theoretical approaches have been used in gauging and developing LT (Donaldson \& Dunfee, 1994; Mele \& Schepers, 2013). From the 1980s LT has been investigated by sundry researchers in order to explore the adoption and application of social contract by firms (Binmore, 1998; Donaldson \& Pfeffer, 1975), and to outline how they are engaging legitimately with their multiple stakeholders in realising the tenets of social contract (Suchman, 1995; Freeman, 1984). As noted by Dowling \& Pfeffer (1975) organisations exist within the milieu of a super-ordinate system (Parsons, 1960), within which they can enjoy legitimacy as long as their actions are in agreement with wider set of benchmarks of behaviour and values embodied in the "super-ordinate system"' (Campbell, 2000, p. 83). The super-ordinate system, a metonymy for value system, has been characterised as the "hypernorms" (Donaldson \& Dunfee, 1994), which shape organisational practice (Rowan \& Meyer, 1977). Also, judgement about legitimacy of actions is based on these hyper-norms, which are the rationale for explaining fairness, justice and legitimacy (Suchman, 1995) within a social space, as sanctioned by institution imperatives (DiMaggio \& Powell, 1983).

In exploring the connection between legitimacy and ER, it has been noted that ER and by extension HRM should be a defender of the "social contract" (Khan, 2014, p. 3). ER also needs to balance and incorporate the views and interests of employees and diverse stakeholders (Kochan, 2005). However, as observed by Kochan (2005), currently ER and HRM in general is faced with crisis of diminished legitimacy and trust in the eyes of key stakeholders. Thus, ER has failed to deliver on its promise of facilitating inclusive, just and equitable engagement processes and strategies. This understanding has propelled writers (Francis, 2007) to reconceptualise ER and by extension HRM (Legge, 1995). This reconceptualisation materialises in moving the debate on justifying organisational behaviour, such as managerial capture, from strict market-oriented standpoint in mainstream HRM, to debate on social norms and principles that legitimise or delegitimise organisational practice (Koca-Helvaci, 2014). Market-oriented or economic criteria place ER and engagement within the confines of cost minimisation and maximisation of shareholder value, which is legitimised via strategic rationality. This is antithetical to normative legitimacy (Suchman, 1995). LT has been empirically explored in HRM, specifically, ER (Koca-Helvaci, 2015). Using LT, Koca-Helvaci (2015) explores Walmart's depiction of its position towards "associates" and "suppliers" as well as how they differ, even though the organisation communicates an affirmative self-image through both of them. Walmart describes its affiliation with its "associates" as supportive and reciprocally advantageous. Conversely, Walmart presents the image of a philanthropist firm that makes attempt to improve the poor working conditions of its "suppliers" via stringent regulations.

\section{Managerial capture and legitimisation of ER}

Managerial capture started with the rise of managerialism. Managerialism is a business philosophy based on the principles of transaction-cost economics, public choice tenet and agency theory. Managerialist approach to transaction-cost economics explains a way of organisational practice based on the belief that capitalists (employers) are rational entities propelled by competitive, economic self-interest. This organisational philosophy is modelled upon the assumption that humans (managers or capitalists) are by nature homo economicus, that is economic man (Knights \& Roberts, 1983). This philosophy conceives of employers as constantly rational and parochially self-interested agents that habitually advance their 
subjectively-defined interests maximally. It is to this end that Buchanan (1978) refers to capitalists (employers) as "rational utility maximise[rs]"' (our parenthesis, p. 17). Central to managerialism is the celebration of efficiency as opposed to effectiveness (Terry, 1998). Managing for efficiency celebrates saving cost and resources (Pollitt, 1990; Terry, 1998) thereby disregarding employees' interests (and voice) in corporate decision (Hirschman, 1970; Parker, 2002; Kaufman, 2015).

Additionally, managerialism often aligns with neo-liberal ideology as well as organises society and organisation, in particular, in the ways that are hierarchical and undemocratic, meaning that managerialism's vision is organisations in which non-managers have little substantive influence on the key decisions that affect their lives (Klikauer, 2013). As Parker (2002) argues, such situation justifies (and normalises) cruelty and inequality in the workplace and society in general, based on the ideology of fierce capitalism. Thus, managing human resource is not only viewed as a management strategy but also "a larger, more encompassing project which can be described as (global) "managerialism" (Mueller \& Carter, 2005 , p. 370). This is the origin of managerial capture (of employees' voice) (Hirschman, 1970). For Power (1991), managerial capture is concerned with preventing stakeholders' (employees') inputs in decision-making achieved by legitimising unequal power relations in the strategies of ER and engagement. Accordingly, to O'Dwyer (2003, p. 29) managerial capture explains when "organisations adopt a structured approach to engage with stakeholders" or employees. We therefore conceive managerial capture (control) as the process that describes organisational orientation to achieve strategic, positive result for the organisation and its shareholders through the instrumentality of strategic streamlining of decision-making procedures, which affords managers greater autonomy and responsibility over employees (Preston, 2001). This managerial ethos is comparable with strategies of ER in Nigeria, where there are tangible forms of power differentials and centralised decisionmaking system (Fajana, 2009; Otobo, 2016).

Legitimising organisational action has a tendency to give organisational behaviour a stamp of societal approval (Ashforth \& Gibbs, 1990) and social licence to operate (Suchman, 1995). Legitimisation is based on the principle of right and wrong (Leeuwen, 2007). This is also a way of showing conformity to ethical standards and code of conduct regarding organisational action and by extension a way of demonstrating "conformity" to social norms. Consequently, as argued by Leeuwen (2007), legitimisation gives justification and basis for organisational action. Legitimisation is a process of showing right or wrong (Waeras \& Ihlen, 2007). This process can offer prescriptive and ethical high ground for practical necessities. Therefore, social or organisational phenomena such as employee disengagement, employee dis/empowerment, voice marginalisation and related concepts implicated in managerial capture of voice (Hirschman, 1970) could be justified, and can be thus considered to be right or wrong. This mode of rationalisation is premised on precise dominant culturally accepted norms and values (Suchman, 1995). To this end, organisations used for this study rationalise and legitimise their style of ER by leveraging on actions that give an impression of applying globally and nationally recognised codes of behaviour relating to labour and employment, which help to "justify" their actions (Suchman, 1995). In the Nigerian context, this means various processes that allow employers to give an impression of adhering to global and Nigerian labour laws and principles about ER (Okpu, 2016), thereby legitimising and managerially capturing ER (Koca-Helvaci, 2015). Managerial capture helps to situate Nigerian employers' behaviour within standards in ER and engagement such as Employment and Labour Relations Act, Nigeria Employment \& Labour Law, Trade Disputes Act, Labour Act, National Minimum Wage Act and the Pension Reform Act among others (Otobo, 2016; 
ILO, 2005). Further to this, managerial capture explains various strategies that enable and sustain organisational intention to thwart inputs from employees either through traditional unions or non-union employee representations NERs approach in Nigeria.

\section{The Nigerian experience: socio-cultural, economic and employment context}

Given Nigeria's huge human resource and natural endowments, it should be one of the greatest nations in the world (Idemudia, 2010). One of the main reasons for this paradox, among other reasons, is the nature of the country's employment terrain, which undercuts economic prosperity and adds to socio-economic problems of the country (Ahiauzu, 1989). Part of this reality is that employers of labour have upper-hand in ER and engagement particularly since the privatisation of most the country's key organisations by the government. Historically, employees are marginalised in Nigeria given government's support of employers in trade disputes (Iyayi, 2009). This situation has also resulted in "the lack of involvement on the part of workers' representation (trade unions) in policy formulation, which has severe impact on the type of policy (and management strategy) and its implementation" (Oyelere, 2014, p. 2, our parenthesis). This landscape helps to shape Nigeria's economic and employment terrain (Obadina, 1999). These efforts have resulted in increased FDI and growth in sectors such as banking, ICT and oil and gas. It is beyond the remit of this article to offer a full appraisal of the success or failure of these reforms. Nonetheless, the economy continues to be characterised by low per capita income, huge fiscal budget deficit, economic insecurity, high inflation, absence of national social welfare system, high unemployment, unequal power relations between employers and employees, and recently recession $(\mathrm{BBC}, 2016)$.

From a socio-cultural context, Nigerian society is generally collectivist with a traditionally organised master-servant relations system and respect for/acceptance of hierarchy. Nigeria's unique form of socio-cultural and political structure and deference to authority and wealth (Ahiauzu, 1989) celebrate marginalisation of employees' input in ER debate (Otobo, 2016). Authority figures such as managers are customarily recognised by employees as having the "right" answers to employment issues, hence, managers' decisions are not challenged by their subordinates (Trompenaars, 1993). Nigeria is a country largely built on culturalenvironmental dynamic of high power distance (PD) index and paternalism, which makes it susceptible to subordinate-superior relationship arrangement (Ting-Toomey, 1988). In Fajana's (2009) analysis of Nigeria's political leadership, he observed that this landscape democratises disempowerment, builds silos between leaders and followers and impedes decisional inputs from employees. This process managerially privileges employers' interest and inputs over their subordinates. Such socio-cultural landscape inhibits employee voice (henceforth, EV) and constructive criticism, which makes it problematic speaking "truth to power' (Foucault, 1980). Potentially, such system endangers participatory and mutually beneficial ER strategies (MacLeord \& Clarke, 2009). This socio-cultural context helps to normalise and legitimise ER pattern in Nigeria (Okpu, 2016).

\section{Conceptual framework}

Legitimacy theory is traditionally considered from two main perspectives: normative and strategic (Meyer \& Rowan, 1977; Donaldson \& Dunfee 1994). Conceiving legitimacy from the angle of the normative entails justifying action or behaviour by drawing such justification from institutional frame of reference and beliefs, which according to Suchman (1995) is influenced by a number of factors namely norms, values and behaviour assumed acceptable and natural within a social space. In this context, Suchman (1995) locates legitimacy within the purview of institutionalisation, which considers stakeholders' approval or consent to have moral force and ethics. As opposed to the normative (institutional) perspective, the strategic 
approach, relates to the resource-based perspective, founded upon organisational orientation, which organisations appropriate to accomplish organisational selfish goal and financial gain. In the context of this article, this manifests in employment relations strategies (Kaufman, 2011), which can precipitate unequal power relations (Koca-Helvaci, 2015) and instrumental management of human resource. Thus, the rationale to legitimise action, for example ER procedures, is premised on managerialist discourse that privileges ideas of performance and organisational legitimacy (Khan, 2014). Therefore, numerous corporate HRM decisions trigger legitimacy issues. Framing legitimacy essentially by employers' rationality and strategic logic is antithetical to moral legitimacy (Kaufman, 2011, 2015). This process prevents employment strategies of morality (Francis, 2007) as well as prevents balanced perspectives on what constitutes normative legitimacy.

However, in bringing alternative perspectives to bear in Nigeria's ER, CDA can be appropriated. CDA offers critical perspective to organisational discourse (Fairclough, 1992) such as ER strategies, managerial control and suppression of EV in order to rethink strategies of engagement and legitimacy (Koca-Helvaci, 2015). Consequently, CDA can help to reveal the appropriateness of ER strategies - legitimisation processes - by exposing the methods organisations use "to obtain legitimacy" (Waeras \& Ihlen, 2009, p. 86). CDA can also enable understanding whether ER and engagement are decentralised to facilitate collective bargaining and mutual interest representation (Hege \& Dufour, 1995). Accordingly, as argued by Bray, Deery, Wash \& Waring (2005) "CDA has inherent appeal for industrial relations (IR) scholars. It aims to 'uncover, demystify or otherwise challenge dominance ... CDA is thus 'engaged and committed', representing 'a form of intervention in social practice and social relationships"' (p. 10). A CDA approach is thus consistent with industrial relations as a field of study, which is focused on the problem of labour from a social justice perspective. It is also committed to pursuing inter-and multidisciplinary research to further understand issues surrounding work and related phenomena that are sensitive to the differing ideological views from which employer-employee relationship can be evaluated.

While there are various approaches used in analysing discursive legitimisation processes (see Peled-Elhanan, 2010; Vaara, et al., 2006), Leeuwen (1995) has perhaps gone furthest in developing what is often considered as "grammar of legitimisation" (Leeuwen, 2007; Leeuwen \& Wodak, 1999). In what is considered "a profound linguistic analysis" (Siltaoja, 2009, p. 193), Leeuwen (1995) developed four main semantic-functional legitimisation strategies. Relying on Leeuwen's work (1995), this article adds to his four main legitimisation strategies by adding management strategy. Therefore, five legitimation strategies, which were identified, will form five themes to be analysed. See Table 4 for detail on the strategies. The strategies are explained below, starting with authorisation.

- Authorisation: Authorisation strategy is based on the authority of tradition, customs, law or person with authority. According to Leeuwen $(2007,1995)$ authorisation is about legitimising behaviour by taking a cue from esteemed authority and/or universal codes of behaviour.

- Moralisation: This strategy is based on norms and values. It offers moral basis for action, which is about rightness as opposed to wrongness. As noted by Leeuwen (1995) one of the ways to achieve this strategy is through evaluation (using lexes or semantic items that measure/value quality), abstraction (use of lexes that stand for something) and contrast (comparison or analogy).

- Mythopoesis: Mythopoesis is based on legitimisation gained from narratives or storytelling. It is a discursive strategy that relies on narratives to legitimise action (Leeuwen, 
1995). According to McConnell (1982) it is concerned with myth-making. According to Leeuwen (2007) there are two main forms of mythopoesis: moral and cautionary tales. The former relies on storytelling to give an action ethical approval/endorsement; the latter stresses what will follow if a state/condition is not changed.

- Rationalisation: Rationalisation originated from a logos-based justification, which legitimises action by alluding to cognitive validity and legitimation (Green, 2004). Legitimisation provides legitimacy; it entails the process whereby an ideology, act, or process becomes legitimate by its attachment to prevalent values and norms within a specific society. It rationalises organisational goals and efficiency; it also celebrates utility of an action and instrumental approach to ER thereby highlighting function, reason, purpose and outcomes of an action (Vaara et al., 2006). From a discursive angle, rationalisation is the ability to give reasons and, accordingly, link claims with justifications and rationality (Hajek \& Samec, 2017). To be rational is to make persuasive sense. So, the more persuasive the discursive reasons supporting a managerial practice, the more rational its adoption. As these reasons are taken-for-granted, managerial practice becomes more institutionalised, acceptable and normalised (Leeuwen, 1995; Leeuwen \& Wodak, 1999).

- Management: Discursive strategy of management is used to enable the rationality of reducing ER strategy to employees' contribution to firm's overall goal and sustainability (Greenwood et al, 2008). It gives primacy to product and output over strategies and processes of input as well as endorses market-type ideals. This strategy has comparable tenets with the commodification of relations (Hudson, 2012) in ER (Rubery, Keizer \& Grimshaw, 2016). Also, this strategy makes it difficult (if not impossible) for employees to have inputs in decision-making process, a managerial strategy achieved through bureaucracy, control, shareholder-centric ER and limited dialogue, which potentially celebrates management ideals and centralised decision as well as de-emphasises lack of employee voice (Armstrong, 2009; Hirschman, 1970).

Further, this paper maintains that legitimisation starts with micro-level issue - language choice and use - which frames organisational discourse (meso-level issues) and wider societal issues (macro-level issues) (Fairclough, 2014). Accordingly, Berger \& Luckmann (1966, p. 112) declared that "incipient legitimation is present as soon as a system of linguistic objectification of human experience is transmitted. For example, the transmission of a kinship vocabulary ipso facto legitimates the kinship structure. The fundamental legitimating 'explanations' are, so to speak, built into the vocabulary'. Specifically, we argue that exploring these types of micro-level (discursive elements) can help to understand the contradictions, complexities and ambiguities in legitimisation that easily pass unnoticed with more traditional approaches to text analysis (Wodak \& Meyer, 2009). Thus, texts constitute a sense-making arena, which can help in understanding managerial capture of employee voice in Nigeria (Okpu, 2016). Thus, choice of words (diction) or lexis is not framed essentially by the organisations, but shaped by patrimonial, institutional and cultural paradigms prevalent in a social space (Fairclough, 1995). In operationalising this, lexicalisation - use of lexis or choice of words - is rooted in some definite ideologies, cultures and social norms and values (Dijk, 2008).

\section{Methodology}

This section deals with three main aspects of methodology adopted, which include: method, analytical framework and data source. This begins with method. 


\section{Method}

We adopted a qualitatively, interpretivist method in analysing data. This means words were used to interpret social actuality. We also considered reality as the result of social construction and interaction (Alvesson \& Deetz, 2000). Therefore, we sought an understanding of ER in Nigeria premised on the views of key stakeholders (managerial and non-managerial employers) in relation to managerial capture (Saunders, Lewis \& Thornhill, 2012). The disparity in individuals' views sought through interviews and focus group (and shadow reports) thus support the multiple reality perceptions that are consistent with interpretivist method. Consequently, it was vital to identify a data collection tool that was consistent with qualitative and interpretivist method. Accordingly, as Patton (2012) observed "there is a very practical side to qualitative (research) methods that simply involves asking open-ended questions of people ... in real-world settings in order to solve problems" (p. 89). Hence, the use of interview and focus group. The study is inductive; this means that theory was not tested. However, data gathered shaped new ideas emanating as well as framed direction of research in regards to overall aim and objectives pursued (Silverman, 2006).

Specifically, 9 face-to-face semi-structured interviews were conducted between March and April 2015. Interviews lasted between 50 and 90 minutes. They were digitally recorded and transcribed word-for-word. Interviewees were reminded their confidentiality will be protected and that their honest opinions were sought. Semi-structured interview permits flexibility as well as enables voice inflections, emotions and body language of interviewees to be identified (Saunders et al., 2012), precisely when dealing with sensitive matter such as managerial capture (Okpu, 2016). As noted by Bryman (2012) semi-structured interviews are essentially purposeful methods and discussion formats between two or more people, which aid a researcher to gather specific and rich data that is germane to his/her research's aim and objectives without diminishing the independence of the interviewee. As a two-way communication process, information collected from this exercise not only afforded us answers to issue investigated, it gave us the platform to ask more questions stemming from reaction of interviewees in respect to what can be regarded as a significant response.

Focus group session was conducted same time as interview (between March and April 2015) and lasted about 70 minutes. Focus group is sometimes referred to as "group interviews" or group discussion. It usually involves about 4 to 8 discussants or participants. It helps in getting diverse but congruent views, which interview might not provide Bryman (2012). It is a "information rich"' tool, pertinent to arrive at "data saturation", (Krueger \& Casey, 2000, p. 25), when combined with interview. Data saturation was realised when emerging themes and motifs seemed recurrent (Glaser \& Strauss, 1967) in interview and focus group data collated. Focus group permits respondents (discussants) to give their views rather than be caged by interviewer's pre-conceived notion or bias. The moderator (facilitator), however, ensures purpose of exercise is not defeated (Silverman, 2006). It further encourages participants to give genuine information unconsciously through its interactive mechanism, which increases validity. Focus group sessions help to identify trends in thought and pattern of events without persuasion from the facilitator. Interviews are different from focus group participants, although they are employed in same organisations. Data from these two source will be supplemented with shadow reports (documentary sources) that are externally sourced (Dey, 2007). Shadow reports, which are also called "alternative reports" or "parallel reports" are reports produced by bodies external to an organisation. These reports help to establish accountability and legitimacy of organisational actions; hence, they are not prepared by organisations themselves (Dey, 2007). As noted by Cowton (1998) documentary sources 
do not lend themselves to data "doctoring"; they are thus plausible method of ensuring validity of data source and findings.

Regarding sample size and sampling, interviewees and discussants in both interview and focus group were drawn from Nigerian employees in specific sectors - banking, ICT and petroleum. These participants were quite familiar with ER in Nigeria; hence, they included employees from selected ICT, banking and petroleum firms in Nigeria. Organisations in these sectors are known for poor ER practice and HRM as well as human rights violations (see Idemudia, 2010; Ituma \& Simpson, 2007; Achua, 2008). Accordingly, Oruh (2017) has noted that these organisations are typical of Nigerian society. Also, these organisations were selected because in extant literature on career development and ER, Nigerian employees encounter WLB challenges (Okpu, 2016), non-participatory ER system (Fajana, 2006) and unequal power relations between them and the management (Otobo, 2016). These interviewees include senior managers, middle managers, and line managers and nonmanagerial members of staff (totalling 9 interviewees). Table 1 provides a list of the individuals participating in the research. Likewise, focus group involved 5 employees of selected ICT, banking and petroleum organisations. Focus group sessions comprised senior and middle managers including 3 non-managerial members of staff. Table 2 gives details on focus group brief. In total, 14 individuals were involved. It is worth noting that size is not really an issue in qualitative research methods (Bryman, 2012). What matters is data saturation (Patton, 2012), which helps a researcher to know if he/she has derived prerequisite knowledge on the phenomenon investigated capable of engendering informed findings and conclusion (Saunders et al., 2012). We arrived at data saturation as our iterative reading of text produced no new insights (or themes) (Silverman, 2006). Also, shadow reports (documentary reports) of two organisations: International Labour Organisation (ILO) and (United Nations) Committee on the Elimination of all Forms of Discrimination against Women $(C E D A W)$ were triangulated with other data. These reports highlight some vital points noticed in both interview and focus group; they are also applied to supplement data, given the limitation of qualitative research (Silverman, 2006). See Table 3 for details.

\section{Analytical framework}

Data was transcribed manually. We iteratively went back and forth data to locate overriding themes that bordered on managerial control, EV suppression, marginalisation, lack of engagement and the strategic pursuit of organisational goals, among related phenomena. We use CDA to analyse how ER strategies and pattern are legitimised in Nigeria. In operationalising CDA, we use texts extracted from the three main data sources - shadow reports, focus group and interview - as a reflection of culture of ER in Nigeria (Fairclough, 1992). CDA helps to reveal human experience in the cultural (Fairclough, 2003), economic (Graham \& Luke, 2011), ideological (Fairclough, 1992, 2014) political (Peled-Elhanan, 2010) and social (Wodak \& Fairclough, 1997). According to Wodak (2000), CDA is a language tool, which helps to understand how organisational behaviour is legitimised through discourse.

As a framework for understanding text and context (Wodak \& Meyer, 2009), CDA interrogates how rhetoric enable an understanding of how power discourses are constructed, reproduced and legitimised institutionally (Fairclough, 2003). This is what Lawton (2013, p. 107) refers to as understanding "language in use". Thus, CDA

... mainly focuses on the notions of power and ideology, examining 
how 'discursive practices' ... can help produce and reproduce unequal power relations between (for instance) social classes ... through the ways in which they represent things and position people (Wodak \& Fairclough, 1997 as cited in Holloway \& Daymon, 2010, p. 168).

Thus, legitimisation strategies such as authorisation, management, rationalisation, moralisation and others loom large in lexical patterning (Fairclough, 2003) that seeks to reveal (and legitimise) the nature of ER (Leeuwen, 1995) and managerial capture.

After painstakingly going through text corpuses, five discursive strategies were consistent in data, and therefore deserve exploration. They also portray intertextuality (congruence) in themes from different sources (Kristeva, 1980). This process is what Dijk (2008) calls thematic "coherence", which Wolf (2004) equates with "single kernel" recognisable pattern that shapes lexical patterning. Lexical patterning deals with word choice and its creation strategies (Fairclough, 2014). Lexical patterning - lexicalisation - helps to explain the mesoand macro- issues that are implicated in use of language (micro-level issue). Lexicalization is implicated in ideology, which is a "mosaic of cultural conventions, economic, social and political belief system as well as institutional norms and values (Dijk, 2008). In fact, Lassen, Strunck, Vestergaad (2006) advised that we have to really "peep into the fundamental ideological connotation behind every piece of communication (discourse) so as to appropriately understand rationale for choice of word (lexical choices). Lexis is an amount of linguistic coding in text creation at which truths can be embodied (or misrepresented) with good measure of freedom and leverage. Therefore, word choice establishes freedom of diction in managing and coding truths (facts) such as ER (Carley, 1992). Central to lexicalisation (semantic-functional analysis) is that social cognition is formed (and shaped) by internal mental structures, such as language, which is created as people draw inferences and gather information about their social environment (Carley, 1992). CDA helps to understand thematic relationship existing in language choice as well as links this to wider societal issues (Wodak \& Meyer, 2009; Fairclough 1992, 2003).

\section{Data source}

We used Multi-Method Qualitative Study (MMQS). This is a methodological process that encourages use of multiple data sources (Saunders et al., 2012), which is essentially a mixture of semi-structured interview, focus group and shadow reports analysed qualitatively. In ensuring anonymity and confidentiality of information in Tables 1 and 2, it is coded for ethics (Bryman, 2012).

Place table 1 here

Place table 2 here

Place table 3 here

\section{Findings and discussion}

Findings and discussion was undertaken by semantically analysing lexes (words) in data. As a semantic-functional study - based on the function and meaning of words - analysis focuses 
on meaning of lexes (Leech \& Short, 2007) in relation to managerial capture in ER. In order to undertake the analysis, reference is made to Table 4.

Place table 4

\section{Authorisation}

This strategy is about basing action on established authority (Leeuwen, 1995). For example, during focus group session a participant said: "My company has always ensured people work towards universal standards on employer-employee relations. We're committed to disciplining anyone that deviates from this. All over the world, standards set the pace for engagement style" (FGB1). The manager from the banking sector uses words such as "standard", "universal" and "all over the world"' to lend credibility to his firm's ER. The choice of words is connotative of global standards such as ILO benchmarks, Nigeria's Employment and Labour Relations Act, Employment \& Labour Law and others used to justify ER (Suchman, 1995; ILO, 2005). Lexicalisation of "universal" standard is a discursive strategy to echo widely held notions about acceptable standards of ER. However, ILO's principles on ER and unionism are not upheld in Nigeria: "Contrary to ILO precepts, strikes in the essential services, including the oil and gas industry, are totally forbidden in Nigeria', (ILO, 2005, pp.19-20).

Additionally, the impact of language (micro-level element) on legitimising organisational action through discourse, (meso-level element) including ER practice and standards, which in turn reflect social realities (macro-level elements) is central to CDA (Fairclough, 1995, 2000). Discourse is a definite way of talking and understanding the world (Jorgensen \& Phillips, 2002). Through use of language power discourses are constructed, reproduced and legitimised (Fairclough, 2014), which helps to frame an "over-determined" identity and difference (Wodak \& Meyer, 2009) as well as construct and maintain social reality (Wodak \& Meyer, 2009). According to Spence (2007), this process facilitates suppressing other voices and maintaining a particular ideology and worldview. Thus, the lexes in these excerpts help to legitimise Nigerian companies' ER actions as well as facilitate a negation of employees' voice, hence, their actions are rationalised on taking a cue from universal standards, which are lodged in language use (Fairclough, 2003).

In offering more insights into such managerialist HR strategy, an interviewee in the petroleum sector supports this argument: "All we get is that they're not breaking the law nor deviating from the norm" (IP2). Similar perspective is shared by both FGICT1 and IICT1. Beyond semantic impact (locution), the construction such as: "What shall we do when some people are ungovernable?" (IB1) performs at an unconscious level. This is referred to as illocutionary force (Austin, 1976). Illocutionary force is a speech act construction that facilitates the process of changing social reality on an issue, such as, non-compliance (of employees) with universal standards. However, echoing global standards also leads to making employees and other stakeholders change their views about ER in Nigeria. Austin (1976) refers to this process as perlocutionary effect, which is actual effect of speech act. This intention is discursively achieved via speech act. As argued by Fairclough (2003), CDA is used to clarify how sociocultural knowledge is related to the performance of what is called speech act. Moralisation strategy continues here: "My manager often rationalises his action by telling us to look at our terms of contract" (IB3). Similar view is painted here: "What we're doing is not contradicting what is already known and done by others even beyond the shores of Nigeria', (FGP1). 


\section{Moralisation}

This strategy presents moral basis of action. In our material, this is achieved by presenting management strategy about employer-employee engagement as fair and with highest standard, which discursively makes it ethical and legitimate (Vaara \& Tienari, 2008). It also helps to suppress EV. Some examples will suffice: "We operate with the highest standards of respect for human rights and integrity ..." (FGB1). "As a corporate leader in corporatestakeholder relations, we're committed to tackling headlong unidirectional engagement process, which some don't care about" (FGP1). The use of linguistic items "highest standards" "some don't care about" and "tackling headlong" is a superlative, moralised discourse accentuating human rights protection, which is a controversial subject in Nigeria's ER (Iyayi, 2009; Ubeku, 1983). Here, hyperbole, a figure of speech that exaggerates a situation or action (Sert, 2008), is used in the three excerpts, to normalise ER style and general management style. Additionally, these lexes are employed to showcase accountability and morality (Leeuwen, 2007) about ER, which masks managerial capture (Power, 1991). It is also a discursive strategy to attenuate "the consequences of the uneven enforcement of labour legislation', (Wood, 2008, p. 329) in Nigeria. These lexes have forceful confirmation (Laine, 2010) of employers' effort at guaranteeing employees' right and further legitimisation of their actions (Okpu, 2016), which is premised on contrast and evaluation (Leeuwen, 2007).

As a foil to this perspective, IICT2 maintains that his company "leaves" them "out of the equation when it comes to fair representation'. This is supported by CEDAW's (2008) statement that ER pattern in Nigeria "show(s) the imbalance in power relations" (p. 23), which is characteristic of Nigerian socio-cultural workplace and experience (Ahiauzu, 1989; Obadina, 1999). Nigeria's high power distance (PD) index also negates the validity of multiple voices in ER (Payton, 2016), which creates a culture and work climate of masterservant relationship (Ting-Toomey, 1988). Also, such discursive rhetoric is aimed at closing "legitimacy gap" (Sethi, 1975). According to Sethi (1975) "legitimacy gap" is an expectancy lacuna representing a discrepancy between an organisation's actions and society's expectations of this organisation. This situation parallels the discrepancies in what Nigerian companies say they do regarding ER and what actually is reality (Oyelere, 2014). As argued by Fajana \& Shadare (2012) the state does not stand as impartial arbiter in the rather skewed agenda of employers, rather it seeks to promote interest of employers (capitalists). Indeed, the moralisation of ER questions the existence of ethical strategies of ER in Nigeria; it also raises incredulity about employers' corporate leadership and commitment to fair ER processes (Leeuwen, 2007). Similarly, views shared by most interviewees and focus group discussants highlight "representation gap", (Acas, 2012, p. 2), a metonymy for "legitimacy gap", which materialises in strategies and processes of ER in Nigeria.

\section{Mythopoesis}

Making reference to earlier incidents via narratives, such as, testimonials, helps to legitimise and normalise action, which mythopoesis does (Wodak, 2001). Both Siltaoja (2009) and Peled-Elhanan (2010) used similar discursive approach to empirically reveal discursive construction of a "socially responsible organisation" (p. 191) by a Finnish newspaper company and legitimisation of massacre in Israeli school history book respectively. Some of these mythopoetic elements include FGP1's statement: "A recent visit by inspectors shows ... we're not mere market followers in effective employer-employee relations". Use of "expert witness" (Vaara et al., 2006) is a discursive stratagem to foreground socially sanctioned, participatory ER, hence, use of pre-existing narrative (expert testimonial) as a 
fountain of logic (Leeuwen, 2007). This strategy helps to mask managerial capture of EV (Wodak \& Meyer, 2009).

However, the perspective of ER painted by CEDAW (2008) helps to fracture this logic: "high unemployment rate in Nigeria coupled with a weak or near absence of effective regulatory mechanism on labour issues in the organised private sector" (p. 43), incubates and fosters non-participatory ER. The mythopoetic construction: "high unemployment rate in Nigeria" signifies that the deployment of expert witness is a discursive ploy to take attention away from the fact that employers take a cue from wider socio-economic and employment realities in Nigeria, as basis for their ER practice (Oyelere, 2014; Fajana, 2009). So, the perspective offered by CEDAW serves as a euphemism for lack of participatory ER strategy. This debate continues here: "My company ... often gets quest speakers to educate us on labour relations" (IB2). Also, a manager from the ICT sector says thus: "What we're doing is exactly what our sister company does about employment" (IICT1). Phrases like "guest speakers" and "our sister company" help to launch mythopoetic construction to naturalise ER practice (Vaara et al., 2006). Deductively, the legitimisation approach by Nigerian employers has ramifications beyond the remit of companies explored; it is part of widespread method of engaging employees in Nigeria.

\section{Rationalisation}

In our data, rationalisation foregrounds efficiency rationality obtained by culturally sanctioned logic to legitimise action. While there are different forms of rationalisation, we focus on "instrumental rationalisation" (Vaara et al., 2006). In our data, this strategy is premised on achieving a firm's long-term goal, purpose and outcomes by emphasising the utility of actions around ER (Vaara et al., 2006). This strategy is realised by applying, for instance, lexical items such as purposive so and to, because, in order to, etc. to legitimise ER (Leech \& Short, 2008). For example, the purposive to construction - " ... to promote mutual co-existence between our firm and us in our corporate goal" (IICT3) - is used to make a deontological impression, which justifies firm's behaviour regarding ER. Financialisation is also deployed to realise rationalisation. Financialisation plays a pivotal role in this statement: "In order for us to survive in this austere business climate, we have to accept whatever the management says"' (FGP2). FGB2's opinion lends credence to this: "a competitive business time such as we have now makes it difficult to challenge management". Similar view is held by a senior manager in the petroleum sector: "We have made it clear to our workers that we will continue to make profit no matter what happens" (IP1). Indeed, rationalisation emphasises the strategic, instrumental orientation of Nigerian firms and consequent reliance on the economic outlook of the country to perpetuate unfair, non-participatory ER practice (Holst, 2014). These above excerpts illustrate that rationalisation relies largely on economic utility and financialisation to legitimise employers' action. Likewise, Vaara \& Tienari (2002) explored rationalistic discourses in merger and acquisition (M\&A) to emphasise the creation of economic value for firms. Accordingly, rationalistic discourse foregrounds legitimation as well as stresses effects, goals and benefits of an action (Green, 2004).

Moreover, views echoed by ILO, CEDAW, FGICT1 (employee from ICT sector) and senior manager in petroleum (IP1) demonstrate that both managers and other members of staff across sectors studied emphasise companies' insistence on achieving instrumental gain. This organisational goal is rationalised and further naturalised by sometimes stating purpose, reason and utility of action about ER, which helps to marginalise employees' voice and further economic interest of firms (Hirschman, 1970; Kaufman, 2015). For example, FGICT1 notes that his company "always takes aggressive action against strike by workers because 
failure to do so will be bad for the firm', hence, it stands in the way of achieving productivity (ILO, 2005). This idea finds correspondence in IP1's view: "As managers, we're usually in the good books of my organisation when we ensure there's no strive action, so as to keep productivity wheel moving". The lexis "aggressive" including the subordinate conjunction "because failure to do so" and phrase "so as to keep" aid to establish strategy of rationality, which helps to normalise instrumental action. Also, the phrase "good books" is a metaphor for bonus or promotion that managers are given when they use their position to ensure that organisational instrumental, strategic objectives are realised. They thus, serve as agents of capitalist ideology (Fairclough, 2000). The connection between language and organisational behaviour and wider economic practices, such as, financialisation and managerialism, are made revealed in these excerpts. They help to endorse the rhetoric of "the Market Rules", which characterises ER in Nigeria (Otobo, 2016; Ubeku, 1983).

\section{Management}

Management strategy is used to enable the rationality of reducing ER strategy to employees' contribution to firm's overall goal and sustainability (Greenwood et al., 2008). This strategy manifests essentially as an instrument of managerial control and lack of engagement in our data. Essentially, lack of engagement connotes voice marginalisation and centralised decision-making (Hirschman, 1970), a managerial strategy achieved through bureaucracy, control, shareholder-centric ER and limited dialogue, which potentially celebrate management ideals (Armstrong, 2009). For instance, IP3's answer when he was asked about the nature of trade unionism in his company corroborates this: "My company's decision to discipline me and further set tough measures for everyone, when I attended a trade union meeting was stringent, to say the least". Focusing on an individual to achieve management objective is what Iyengar (1991) calls "episodic framing", which describes a single case that warrants blaming or punishing a group rather than an individual. Rather than blame or discipline this employee only (IP3), further tough measures were set for all employees. Analogous perspective is showcased here: "Unions are seen as obstruction to corporate goal in my company" (FGB1). Such statement from a manager underscores corporate ideal about ER (Holst, 2014). In these instances, management of these companies consider trade unions as threat to their success; hence, employees' membership and relationship with unions can be detrimental to their sustainability and organisational goal. However, as argued by Beckman (2009, p. 184) "unions are capable of offering leadership and building broad alliances and thus asserting a wider popular democratic influence" as they open alternative platforms to address workers' grievances, rights and welfare as well as voice amplification (Kaufman, 2015).

The workplace environment painted here negates such as well as impinges on social dialogue, which is capable of balancing power relations and accelerating democratic ER. Thus, "social dialogue requires the positive participation of trade unions which also represent the voice of their members and communities at large"' (ILO, 2005, p. 33). Thus, on the part of employers, ER is not a jointly negotiated agreement; it is rather a strategy to advance corporate interest and shareholder value, which helps to legitimise corporate capture. Also, such ER strategy marginalises and suppresses voice of employees in decision-making processes as the primacy of product and output over processes of input are encouraged (Vaara et al., 2006); it equally endorses market-type ideals, which Hudson (2012) argues promotes the commodification of relations. Okpu (2016) concurs to this argument, and further sees it as the pursuit of management objectives. This perspective continues here: "It's difficult to have a voice when what you say is not put into consideration so as to avoid opposition in my company, and involving unions brings sanction', (IICT2). This excerpt suggests that joining trade unions or 
going contrary to organisational strategy or goals by way of voicing out concerns could be detrimental to workers, which FGB1, a manager from the banking sector acknowledges as well as other managers and non-managerial members of staff. Lexical items, such as, "sanction", "difficult", [lack of] "voice", "discipline", and "so as to avoid opposition" among others help to paint a picture of unfair, managerially-oriented ER. According to Wodak \& Meyer (2009) lexical/linguistic items (micro-level elements) help to construct organisational discourse (meso-level issues, for example, ethical ER strategy) that ultimately frames political, economic and ideological issues in society, that is, macro-level issues. Thus, these linguistic items reflect larger societal issues, such as, "(global) managerialism" (Mueller \& Carter, 2005, p. 369) and "global neo-liberal capitalism" (Fairclough, 2000, cited in Mueller \& Carter, 2005, p. 370).

\section{Summary and conclusions}

We began by suggesting that prior studies have focused attention on legitimacy (legitimisation), however, the discursive aspects of this concept have largely remained underexplored (Suddaby \& Greenwood, 2005). This essentially the case with ER studies and HRM in general, where authors have paid less attention to discursive legitimisation strategies (Francis, 2007). As we have demonstrated, CDA aims to highlight the relations of causality and determination between discursive practices, events and texts as well as wider cultural structures to investigate how such practices arise and ideologically shaped by relations of power and struggle over power (Fairclough, 2014). This approach has been empirically explored (Vaara \& Tienari, 2008) specifically in ER (Francis, 2007). We have thus argued that CDA provides a finer-grained and useful - although not the only possible - framework to critically orientated exploration of controversial ER issue (in Nigeria), which is in the shadow of managerial capture (Otobo, 2016). This approach is a way of responding to the call by Bailey et al. (2009) and others (Legge,1995; Watson, 2004) to expand the confines of HRM, ER and voice literature in order to trigger a renewed consciousness in management studies. In the main, our study demonstrates the centrality of discursive strategies such as authorisation, moralisation, mythopoesis and rationalisation (Leeuwen, 2007) and to add management, which are concrete discursive ways through which ER can be better understood (in Nigeria).

Part of the conclusions of this paper is that Nigerian companies' ER strategies and processes are managerially structured to facilitate managerialist ideology and shareholder-centric practices. Such organisational behaviour and ER practice helps to promote management control, suppression of EV, lack of employer-employee engagement, and marginalisation of employees' input in decision-making process. This situation creates and fosters managerial capture of EV. The sectors explored demonstrate comparable situation about ER pattern in Nigeria as well as indicate similarity of views expressed by both managers and nonmanagerial members of staff across companies. Also, each of the discursive strategies analysed in our material (interviews, focus group and shadow reports) shows how ER is managerially captured and normalised, which helps to legitimise organisational practice. However, whilst other discursive legitimisation strategies are used more, mythopeisis strategy does not feature regularly as other strategies. Nevertheless, these strategies signify the need to rethink ER and HRM in Nigeria in order to better understand whether EV is realised or not in the managerially propelled employer-employee relations discourse in Nigeria.

First, one of the contributions of this paper is the use of rare source - shadow report - which is combined with interview and focus group data to demonstrate managerial capture of ER in Nigeria. This process can help to advance research on prior studies in developing countries, such as Nigeria (Budhwar \& Debrah, 2004). Second, by adopting CDA, we provide insight 
into the linguistic resources organisations as power elites use to portray a positive self-image by legitimising behaviours that test their legitimacy (Koca-Helvaci, 2015). Second, our analysis has made some vital contributions by way of offering more nuanced method of understanding the processes through which Nigerian employers legitimise their actions, while de-legitimising actions of employees (Okpu, 2016). Third, the addition of management legitimisation strategy builds on prior literature on institutional oriented studies and legitimacy about ER that is understudied (Koca-Helvaci, 2015).

As our paper includes a number of possibilities, it also has some limitations. For example, CDA has emerged as a framework to investigate organisational life (Wodak \& Meyer, 2009); however, it provides ideological reading of texts, which can be a criticism (Luke, 2002). As asserted by Breeze (2011), it occasionally suffers from "randomness", description and openness to bias, which Widdowson (2005) perceives in studies by Fairclough (1996) and Fowler (1996). It also precludes other aspects of text analysis by focusing on power relations, which potentially makes understanding the other reasons for structuring ER. Thus, other readings can provide different outcomes. Potentially, this characterisation of CDA could constitute bias in our analysis. In light of this potential criticism, we triangulated data to limit such criticism, which includes documentary, interview and focus group data. Thus, we feel there is a vital need to explore ER, CDA and managerial capture through other approaches including quantitative and longitudinal methods, which could further development in research on these concepts. It would also be interesting to compare data used here with other documentary sources such as government publications, newspapers, visual images (semiotics) as well as more traditional sources including survey and ethnography. Moreover, we acknowledge sampling limitation: only employees in specific sectors including banking, ICT and petroleum were involved. However, our detailed linguistic analysis (micro-level elements) can only be productively applied to small sample size (Merkl-Davies \& Koller, 2012). Also, as argued by Creswell (2009) sample sizes are characteristically smaller in qualitative research for the simple reason that, as the study continues, acquiring more data does not necessarily generate more information. And in qualitative research, determining sufficient sample size is in the main a matter of experience and judgement, and it is sometimes based on purposive sampling (Saunders et al., 2012). Therefore, a "limited number of texts is sufficient in a discursive analysis in which small speech acts are seen to reveal significant information and which is aimed to say a lot about a little" (Joutsenvirta, 2011, p. 60).

\section{References}

Acas. (2012). Voice and Participation in the Modern Workplace: challenges and prospects. Acas Future of Workplace Relations. Discussion Paper Series. Http://www.acas.org.uk/.../Voice and_Participation_in the Modern_Workplace challenges. (Accessed 16/01/2017).

Achua, J. K. (2008). Corporate social responsibility in Nigerian banking system. Society and Business Review, 3 (1), pp. 57-71.

Ackroyd, S., Burrell, G., Hughes, M., and Whitaker, A. (1988). The Japanisation of British industry? Industrial Relations Journal, 19 (1), pp. 11-23.

Ahiauzu, A. I. (1989). The "Theory A" system of work organisation for the modern African workplace. International Studies of Management and Organisation, 19 (1), pp. 6-27. 
Alvesson, M. and Deetz, S. (2000). Doing critical management research. London: Sage.

Armstrong, M. (2009). Armstrong's handbook of human resource management practice. London: Kogan Page.

Ashford, B. E. and Gibbs, B. W. (1990). The double-edge of organisational legitimation. Organisation Science, 1(2), pp. 177-194.

Austin, J. L. (1976). How to do things with words. Oxford: Oxford University Press.

Bailey, J., Townsend, K. and Luck, E. (2009). Workchoices, imagechoices and the marketing of new industrial relations legislation. Work, Employment and Society, 23 (2), pp. 285-304.

BBC. (2016). Nigerian economy slips into recession. Http: //www.bbc.co.uk/news/business$\underline{37228741}$ (Accessed 26/01/ 2017).

Beaumont, P., Hunter, L., and Sinclair, D. (1996). A 'partnership 'route to human resource management? Journal of Management Studies, 33 (2), pp. 235-257.

Beckman, B. (2009). Trade unions and popular representation: Nigeria and South Africa compared. In: O. Törnquist., N. Webster., and K. Stokke. (eds). Rethinking Popular Representation. New York: Palgrave Macmillan, pp.179 -95.

Berger, P. L. and Luckmann, T. (1996). The social construction of reality: A treatise in the sociology of knowledge. Hamondsworth, Middlesex: Penguin Education.

Binmore, K. (1998). A utilitarian theory of political legitimacy. In: N. A. Ben and L. Putterman. (eds.). Economic Values and organisation, pp. 101-132.

Bray, M., Deery, S., Walsh, J., and Waring, P. (2005). Industrial relations: A contemporary approach. ( $3^{\text {rd }}$ edn). Sydney: McGraw-Hill.

Breeze, R. (2011). Critical discourse analysis and its critics. Pragmatics, 21, 4, PP. 493-525.

Bryman, A. (2012). Social research methods. (4th edn). New York: Oxford University Press.

Buchanan, J. M. (1978). The economics of politics. Transatlantic Arts.

Budhwar, P. and Debrah, Y. (2004). Introduction: HRM in developing countries. In: P. Budhwar and Y. Debrah. (Eds.). HRM in Developing Countries. London: Routledge, pp. 115.

Campbell, D. J. (2000). Legitimacy theory or managerial reality construction: Corporate social disclosure in Marks and Spencer corporate reports, 1969-1997. Accounting Forum, 24 (1), pp. $80-100$.

Carley, K. and Palmquist, M. (1992). Extracting, representing, and analysing mental models. Social forces, 70 (3), pp. 601-636. 
CEDAW. (2008). The Nigeria CEDAW NGO Coalition Shadow Report 2004-2008. New York: United Nations Committee on the Elimination of All Forms of Discrimination Against Women, June 30-July 18.

Chiper, S. (2006). The discourse of Romanian universities. Journal of Organisational Change Management, 19 (6), pp. 713-24.

Cowton, C. J. (1998). The use of secondary data in business ethics research. Journal of Business Ethics, 17 (4), pp. 423-434.

Creswell, J. W. (2009). Research design: qualitative, quantitative, and mixed methods approaches. London: Sage.

Deephouse, D. L. and Suchman, M. (2008). Legitimacy in organisational institutionalism. In: The Sage handbook of organisational institutionalism. R. Greenwood, C. Oliver, R. Suddaby \& K. Sahlin. (eds), 49-77.

Dey, C. (2007). Developing silent and shadow accounts. In: J. Unerman., J. Bebbington. and B. O'Dwyer. (eds.). Sustainability Accounting and Accountability. London: Routledge, pp. 307-26.

Dijk, van, T. A. (2008). Discourse and context: A socio-cognitive approach. Cambridge: Cambridge University Press.

DiMaggio, P. J. and Powell, W. W. (1983). The iron cage revisited: Institutional isomorphism and collective rationality in organisational fields. American Sociological Review, 48, pp. 14760 .

Donaldson, T. and Dunfee, T. W. (1994). Toward a unified conception of business ethics. New York: Oxford University Press.

Dowling, J. B. and Pfeffer, J. (1975). Organisational legitimacy: Social values and organisational behaviour. Pacific Sociological Review, 18 (1), pp. 122-136.

Fairclough, N. (1992). Discourse and social change. Oxford: Blackwell.

Fairclough, N. (1995). Critical discourse analysis: The critical study of language. London: Longman.

Fairclough, N. (1996). A reply to Henry Widdowson's 'Discourse analysis: A critical view'. Language and Literature, 5, 1, pp. 49-56.

Fairclough, N. (2000). Guest editorial: language and neo-liberalism. Discourse and Society, 11 , pp. 147-8.

Fairclough, N. (2003). Analysing discourse: textual analysis for social research. London: Routledge.

Fairclough, N. (2014). Critical language awareness. London: Routledge.

Fairclough, N. and Wodak, R. (1997). Critical discourse analysis. In: T. van Dijk. (Ed). Discourse as social interaction. London: Sage. 
Fajana, S. and Shadare, O. A. (2012). Workplace relation, social dialogue and political milieu in Nigeria. International Journal of Business Administration. 3 (1), pp.75-83.

Fajana, S. (2009). HR management in Africa: The social and economic framework. Personalfurung, 7, pp. 80-86.

Ford, M. and Gillan, M. (2016). Employment relations and the state in Southeast Asia. Journal of Industrial Relations, 58 (2), pp.167-182.

Foucault, M., (1980). Language, counter-memory, practice: Selected essays and interviews. New York: Cornell University Press.

Fowler, R. (1996). Linguistic criticism. Oxford: Oxford University Press.

Francis, H. (2007). Discursive struggle and the ambiguous world of HRD. Advances in Developing Human Resources, 9 (1), pp.83-96.

Freeman, R. E. (1984). Strategic management: A stakeholder approach. Boston: Pitman.

Glaser, B. G. \& Strauss, A. L. (1967). The discovery of grounded theory: strategies for qualitative research. Chicago: Aldine Publishing Company.

Graham, P. and Luke, A. (2011). Critical discourse analysis and political economy of communication: Understanding the new corporate order. Cultural Politics, 7 (1), pp.103-132.

Greenwood, M. R. (2002). Ethics and HRM: a review and conceptual analysis. Journal of Business Ethics, 36 (3), pp. 261-278.

Greenwood, M. R. (2012). Ethical analysis of HRM: a review and research agenda. Journal of Business Ethics, 114, 2, pp. 355-366.

Green, S. E. (2004). A rhetorical theory of diffusion. Academy of Management Review, 29 (4), pp. 653-669.

Greenwood, R., Oliver, C., Suddaby, R., and Sahlin-Andersson, K. eds. (2008). The Sage handbook of organisational institutionalism. London: Sage.

Hajek, M. \& Samec, T. (2017). Discourses of thrift and consumer reasonability in czech state-socialist society. Czech Sociological Review, 53 (6), pp. 805-831.

Hege, A. and Dufour, C. (1995). Decentralisation and legitimacy in employee representation. European Journal of Industrial Relations, 1(1), pp.83-99.

Hirschman, A. (1970). Exit, voice and loyalty: Response to decline in firms, organisations and states. Cambridge: Harvard University Press.

Holloway, I. and Daymon, C. (2010). Qualitative research methods in public relations and marketing communications. New York: Routledge.

Holst. H. (2014). Commodifying institutions: Vertical disintegration and institutional change in German labour relations. Work, Employment and Society 28 (1), pp. 3-20. 
Hudson, M. (2012). Finance capitalism and its discontents. Dresden: Islet.

Idemudia, U. (2010). Corporate social responsibility and the rentier Nigerian state: Rethinking the role of government and the possibility of corporate social development in the Niger Delta. Canadian Journal of Development Studies, 30 (1), pp. 131-153.

ILO. (2005). Industrial relations in the oil industry in Nigeria. Working Paper 237. Genera: ILO.

Ituma, A. \& Simpson, R. (2007). The 'boundaryless' career and career boundaries: Applying an institutionalist perspective to ICT workers in the context of Nigeria. Human Relations, 62(5):727-761.

Iyayi, F. (2009). The casual texture of trade union environments. Global Journal of Social Sciences, 8 (2), pp. 77-87.

Iyengar, S. (1991). Is anyone responsible? How television frames political issues. University of Chicago Press: Chicago.

Jorgensen, M. \& Phillips, L. (2002). Discourse analysis as theory and method. London: Sage.

Joutsenvirta, M. (2011). Setting boundaries for corporate social responsibility: firm-NGO relationship as discursive legitimation struggle. Journal of Business Ethics, 102, (1), pp. 5775.

Kaufman, B. (2011). Comparative employment relations: Institutional and neo-institutional theories. In: M. Barry and A. Wilkinson. (Eds). Research Handbook of Comparative Employment Relations. Northampton: Algar, pp. 25-55.

Kaufman, B.E. (2015). Theorising determinants of employee voice: an integrative model across disciplines and levels of analysis. Human Resource Management Journal, 25 (1), pp.19-40.

Khan, M. B. (2014). Ethical Human resource management (EHRM): A critical analysis. The BAM 2014 Conference Proceedings.

Klikauer, T. (2013). Managerialism: A critique of an ideology. Hampshire: PalgraveMacmillan.

Knights, D. and Roberts, J. (1983). Understanding the theory and practice of management control. Employee Relations, 5(4), pp.1-43.

Koca-Helvaci, Z.C. (2015). Walmart and its employee relations: organisational stance-taking and legitimacy. On the Horizon, 23 (4), pp. $374-386$.

Kochan, T. A. (2005). Restoring the American dream: A working families' agenda for America. Cambridge: MIT Press.

Kochan, T. A. (2004). Restoring trust in the human resource management profession. Asia Pacific Journal of Human Resource Management, 42 (2), pp.132-146

Kristeva, J. (1980). Desire in language: A semiotic approach to literature and art. New York: Columbia University Press. 
Krueger, R. A. and Casey, M.A. (2000). Focus groups: A practical guide for applied research. Los Angeles.

Laine, M. (2010). Towards sustaining the status quo: Business talk of sustainability in Finnish corporate disclosures 1987-2005. European Accounting Review, 19 (2), pp. 247-274.

Lassen, I., Strunck, J. and Vestergaard, T. (2006). (Eds). Mediating ideology in text and image: ten critical studies. Amsterdam: John Benjamins, pp. 19-35.

Leech, G. and Short, M. (2007). Style in fiction: A linguistic introduction to English fictional Prose. ( $2^{\text {nd }}$ Ed.). London: Longman.

Leeuwen, T. V. and Wodak (1999), R. Legitimising immigration control: A discourse historical analysis. Discourse and Society, 1 (1), pp. 83-118.

Leeuwen, T. V. (1995). The grammar of legitimation. London: School of Media, London College of Printing.

Leeuwen, T. V. (2007). Legitimation in discourse and communication. Discourse and Communication, 1(1), pp. 91-112.

Legge, K. (1995). Human resource management: Rhetoric and realities. London: Macmillan.

Luke, A. (2002). Beyond science and ideological critique: Developments in critical discourse analysis. Annual Review of Applied Linguistics, 22, pp. 96-110.

Luyckx, J. \& Janssens, M. (2016). Discursive legitimation of a contested actor over time: The multinational corporation as a historical case (1964-2012). Organisation Studies, 37, (11), pp. 112-134.

MacLeod, D. \& Clark, N. (2009). Engaging for success: Enhancing performance through employee engagement. Report to Government. London: Department for Business, Innovation and skills.

McConnell, F. D. (1982). Storytelling and mythmaking: Images from film and literature. Oxford: Oxford University Press.

Mele, V. and Schepers, D. (2013). E pluribus unum? Legitimacy issues and multi-stakeholder codes of conduct. Journal of Business Ethics, 118 (3), pp. 561-576.

Merkl-Davies, D., Brennan, N. and McLeay, S. (2011). Impression management and retrospective sense-making in corporate narratives: a social psychology perspective. Accounting, Auditing and Accountability Journal, 24, (3), pp. 315-344.

Mueller, F. and Carter, C. (2005). The "HRM project" and managerialism: Or why some discourses are more equal than others. Journal of Organisational Change Management, 18 (4), pp. 369-382.

O'Dwyer, B. (2003). Conceptions of corporate social responsibility: The nature of managerial capture. Accounting, Auditing and Accountability Journal, 16 (4), pp.523-557.

Obadina, T. (1999). Getting the measure of African poverty. Africa Today, pp. 34-38. 
Okpu, T. (2016). Employee voice and workers commitment in Nigerian workplace. Lap Lambert Academic Publishing.

Oruh, E. S. (2017). Managerial capture of employee voice in unionised and non-unionised employee representations (ners) setting: an empirical evidence from Nigeria. Doctoral thesis. Brunel: University of Brunel.

Otobo, D. (2016). (ed). Reforms and nigerian labour and employment relations: perspectives, issues and challenges. Lagos: Malthouse Press.

Oyelere, M. A. (2014). Political developments, trade union and social movement unionism: A case of Nigeria labour congress. Regent's Working Papers in Business \& Management Working Paper 1404: RWPBM1404. London.

Parker, M. (2002). Against management: Organisation in the age of managerialism. Cambridge: Polity Press.

Parson, T. (1960). Structure and process in modern society. New York: Free Press.

Patton, M. Q. (2012). Qualitative research and evaluation methods. London: Sage.

Peled-Elhanan, N. (2010). Legitimation of massacres in Israeli school history books. Discourse and Society, 21 (4), pp. 377-404.

Pollitt, C. (1990). Managerialism and the public services: the Anglo-American experience. Oxford: Blackwell.

Power, M. (1991). Auditing and environmental expertise: between protest and professionalism. Accounting, Auditing and Accountability Journal, 4 (3), pp. 30-42.

Rowan, B. and Meyer, J. W. (1977). Institutionalised organisations: Formal structure as myth and ceremony. American Journal of Sociology, 83, pp. 340-363.

Rubery, J., Keizer., A. and Grimshaw, D. (2016). Flexibility bites back: the multiple and hidden costs of flexible employment policies. Human Resource Management Journal, 26 (3), pp. 235-251.

Saunders, M., Phillip, L., and Thornhill, A. (2009). Research methods for business students. ( $5^{\text {th }}$ ed). Harlow: Pearson.

Sert, O. (2008). An interactive analysis of hyperboles in a British TV series: Implications for EFL classes. ARECLS, 5, pp. 1-28.

Siltaoja, M. E. and Onkila, T. J. (2013). Business in society or business and society: the construction of business-society relations in responsibility reports from a critical discursive perspective. Business Ethics: A European Review, 22 (4), pp. 357-373.

Siltaoja, M. E. (2009). On the discursive construction of a socially responsible organisation. Scandinavian Journal of Management, 25, pp.191-202.

Silverman, D. (2006). Interpreting qualitative data. ( $3^{\text {rd }}$ ed.). London: Sage.

Spence, C. (2007). Social and environmental reporting and hegemonic discourse. Accounting, Auditing \& Accountability Journal, 20, 6, pp. 855-882. 
Suchman, M. C. (1995). Managing legitimacy: Strategic and institutional approaches. Academy of Management Review, 20 (3), pp. 571-610.

Suddaby, R. and Greenwood, R. (2005). Rhetorical strategies of legitimacy. Administrative science quarterly, 50 (1), pp. 35-67.

Terry, L. D. (1998). Administrative leadership, neo-managerialism, and the public management movement. Public Administration Review, pp. 194 -200.

Ting-Toomey, S. (1988). Intercultural conflict style: Face-negotiation theory. In: Y. Y. Kim and W. Guddykunst. (Eds). Theories in Intercultural Communication, CA: Sage, Newbury Park, pp.213-235.

Trompenaars, F. (1993). Riding the waves of culture: Understanding cultural diversity in business. Avon: The Bath Press.

Ubeku, A. (1983). Industrial relations in developing countries: The case of Nigeria. London: Macmillan.

Vaara, E. and Tienari, J. (2002). Justification, legitimisation and naturalisation of mergers and acquisitions: A critical discourse analysis of media texts. Organisation 9 (2), pp. 275 304.

Vaara, E. and Tienari, J. (2008). A discursive perspective on legitimation strategies in MNCs. Academy of Management Review, 33 (4), pp. 985-993.

Vaara, E., Tienari, J., and Laurila, J. (2006). Pulp and paper fiction: On the discursive legitimation of global industrial restructuring. Organisation Studies, 27, pp. 789-810.

Wæraas, A. and Ihlen, O. (2009). Green legitimation: the construction of an environmental ethos. International Journal of Organisational Analysis, 17 (2), pp. 84-102.

Watson, T. J. (2004). HRM and critical social science analysis. Journal of Management Studies, 41(3), pp.447-467.

Widdowson, H. (2005). Text, context, pretext: critical issues in discourse analysis. Oxford: Blackwell.

Wodak, R. and Meyer, M. (2009). Methods for critical discourse analysis. (2 ${ }^{\text {nd }}$ Ed.). London: Sage.

Wodak, R. (2000). La sociolingüística necesita una teoría social? Nuevas perspectivas en el análisis crítico del discurso. Discursoy Sociedad, 2 (3), pp. 123-147.

Wodak, R. (2001). The discourse-historical approach. In: R. Wodak and M. Meyer (Eds.). Methods of Critical Discourse Analysis, pp. 63-95. London: Sage.

Wolf, W. (2004). Cross the border-close that gap: Towards an intermedial narratology. European Journal of English Studies, 8 (1), pp. 81-103.

Wood, J. (2008). Introduction: Employment in Africa. Employee Relations, 30 (4), pp. 1-4. 
